\title{
THE ROLE OF RELIGION TEACHER AND STUDENTS' INTEREST IN ISLAMIC SPIRITUAL ACTIVITES AT SMPN 17 BANDUNG
}

\author{
Sitti Chadidjah*, Ajat Syarif Hidayatulloh, Agus Samsul Bassar, Ike Nilawati Rohaenah, \\ Rida Nur Farida, Didik Sunandar Asep Saepulmillah \\ Islamic Education Study Program, Sekolah Tinggi Agama Islam Muhammadiyah Bandung, \\ Indonesia \\ *E-mail : sittichadidjah@staim-bandung.ac.id
}

Website: http://jurnal.uin-antasari.ac.id/index.php/jtiik

Received: 13 June 2020; Accepted: 8 January 2021; Published: 8 January 2021

\begin{abstract}
ABSTRACK
Among the roles of religion teachers are directing students and animating religious extracurricular activities. What motivates the students to take part in Rohis (Kerohanian Islam) extracurricular activities is the students' interest in Islamic religious lessons, and the direction from the religion teacher. The purpose of this study, to examine the role of religion teachers and student interests. relation to spiritual activity. This study uses a descriptive quantitative approach with multiple variables. The respondents are active 8th grade students. Data collection through questionnaires, interviews, observation. Then the data was analyzed, then the correlation was calculated using SPSS 20 and then concluded. The find research religion teachers in guiding and motivating, as well as students' interest in learning religion is closely related to the spiritual activities.
\end{abstract}

Key Words: religion teacher; interests; islamic spirituality; extracurricular.

\section{INTRODUCTION}

Currently, technological advances dominate all lines of life. The conditions of the world of education today are forced to organize education with an online system. Various trainings followed by teachers including Islamic Education teachers at all levels of education. Media technology trumps student interest in things that are natural. Courtesy, obedience, faith, honesty, friendliness is lacking. This digital world greatly influences human behavior, including students of SMPN 17.

Faith and morals are important elements in religion teacher is the main subject in government programs to shape the character of the nation. Through Islamic religious education material which is divided into 4 sub-materials which include Islamic History, Fiqh, morals, Al-Quran and hadith, it has the aim of convincing students to stick to Islamic values.

This affirmation of the strength of character building and faith is in line with the Education Law Number 20 of 2003 concerning the National Education System Chapter II Article 3 which we can underline that national education in Indonesia has a function to make this nation dignified, intelligent and intelligent. life, always develop one's potential. So that this nation becomes a nation with dignity, noble character, faith, and fear of Allah SWT.

Religion teacher which is implemented in schools makes a positive contribution in shaping student life. This is because Islam is the foundation of life on earth. A person's Islam can affect patterns of thought, speech patterns, worship patterns, and attitude patterns in his daily life. So it can be said, if someone is in accordance with the good judgment according to the individual, social society, and conformity with religion. The Koran confirms this in Surah An-Nisa Verse 59, that all believers must obey Allah, obey the Prophet, and obey ulil amri, and if there is a difference of opinion, all believers must obey Allah Almighty and obey the Prophet. His Apostle. This verse is also confirmed in Surah At- 
Taubah, verse 105, that Allah obliges every believer to work.

From the two combinations of these verses, it is known that the suitability of a person's actions and behavior is influenced by understanding and beliefs about religion. So that if it is found that there are many deviations in religious attitudes carried out by humans in various multi-dimensions and across generations, including by students at school, of course these deviations are not due to their religious values. However, this deviation is a result of the lack of knowledge about Islam and is influenced by friends or information circulating in cyberspace, and it can also be caused by a less religious environment, or also family. For this reason, Islamic religious education in schools is given to students with the hope of providing additional scientific insight and coloring students' good behavior in accordance with the objectives of the Islamic religion contained in the letter Al-Mujadalah verse 11, that Allah swt exalts those who have knowledge. Islam itself wants humans to be able to apply this knowledge to life on earth in accordance with the rules outlined by Allah. So there is a belief that knowledge is not only a science, but it must be practiced and need to be applied in personality, and used for worship.

Education is actually aimed at shaping the moral of a civilized society, or the moralization of society, especially students. So that the meaning of education is not only a rudimentary school (education not only education as schooling), but education is the anchor of society (which is useful for oneself and the community), likes to practice Islamic teachings, and does good deeds.

Religion teachers play an important role in shaping the faith and noble character of students. Among these roles is a motivator, and has competence in teaching. Motivators, teachers must have the ability to increase student interest in learning Islamic Education. While competence in teaching, teachers are able through the learning strategies and learning methodologies of religion teacher to be able to carry out the teaching and learning process properly and measurably. Although sometimes the heterogeneous background of student behavior, especially those that are less common, becomes a challenge in itself, and a solution must be found.

Student learning activities are closely related to interest. In teaching and learning activities, interest means a tendency towards a certain object. Interest is shown through attitudes, for example when they like, feel happy when receiving assignments from PAI teachers, attention in learning, knowing the goals of PAI, knowing the goals of studying PAI, and knowing their interests and goals to join in Islamic spiritual guidance (Rohis).

Rohis is a student activity that aims to improve students' religious attitudes. Islamic spirituality is a form of school business that aims to improve students' religious attitudes in extracurricular activities under the supervision of Islamic Education teachers. The Rohis program which has been running since 2016 must be able to foster interest in learning, increase religious insight, build students' religious attitudes. This activity is realized through group recitation, social service, tadabur alam, mabid, commemoration of Islamic holidays.

This spiritual activity is a religious extracurricular activity, especially Islam. Students who are involved in this activity will deepen three main points in Islamic teachings, namely aqidah, worship that specializes in mahdhoh worship practices, and morals.

Strengthening the three main religions in this Rohis activity is expected to provide goodness and increase the personality of Muslims so that they have better character, provide deeper religious discourse than when learning Islamic Education in class so that it can increase student achievement in Islamic Education subjects, and support students' spiritual talents. .

The explanation above led the author to investigate further about "how is the 
relationship between the role of Islamic Education teachers in this case as a guide and motivator, and student interest in Rohis activities at SMPN 17 Bandung?". In line with the formulation of the problem, this study further aims to prove the relationship between the role of Islamic Education teachers and students' interest in Rohis activities at SMPN 17 Bandung.

The meaning of the word role is referred to as function or position.(Poerwadarminta, 2007) According to Soekanto "role (role) is a dynamic aspect of position (status)" (Poerwadarminta, 2007, p. 870) A person who has exercised his rights and obligations in accordance with his position, means he is playing a role. (Soekanto, 1990, p. 212)The word role also means something that is done in a team or in a particular organization or community that has a purpose. A person is said to have a role if he has exercised his rights and obligations in accordance with his social status.(Abdulsyani, 2002, p.94)

The teacher is an educator who indirectly has to take care of all his actions, both inside and outside the classroom. Students often imitate the teacher by imitating their teacher both in words and deeds. The terms digugu and imitated are still inherent in the teacher. Digugu has the meaning to be trusted. Meanwhile, imitated means being imitated or followed. It can be concluded that a teacher is a person who fights for education from darkness to a brighter direction, avoids stigma, and a narrow mind leads to broad, knowledgeable and meaningful thinking. dwarfism continually strives continuously gradually, to release humans from darkness, get rid of boredom and stunted thinking towards the breadth of thinking and knowledgeable.(Hamka Abdul Aziz, 2012, p. 19)

Spiritual activities of students in every public school such as SMP and SMA in Indonesia are often abbreviated with the word Rohis. This extracurricular activity has proven to be able to attract students to be active, and as a place to improve students' morals. Rohis children are known among schools as students who have good character and obey the school rules. This is a young Islamic movement that aims to preserve Islamic morals and humanist values in behaving and collaborating with friends and fellow people, across people in general.(Muhaimin, 2005, p.68)

Religion teachers have a general role as educators, teachers and mentors of school students, the role of teachers is based on the view of the general public that teachers are related to behavior patterns in interaction, both interactions with students, fellow teachers, and educators (staff).(Djamarah, 2000 , p. 37) In addition, the public's view of religion teachers as members of society who have religious knowledge more than members of society in general, for example, the role of religious teachers in the community as lecturers, teachers who guide reading the Koran, provide religious knowledge, a place to ask questions about religion. Even the role in society is not uncommon for Islamic Religious Education Teachers to be asked by the community to solve problems that occur in the community, for example land disputes, inheritance disputes. It also includes public affairs on religious holidays such as Eid, qurban, walimatul ursy, walimatul shafar, review of the corpse. Specifically in this article, the role of Islamic Education teachers in Rohis activities includes fostering and monitoring activities. Guidance for students in the form of lectures on youth religion, for example youth fiqh, social morals. Briefing students about the issues that occur and tips on how to respond to them. In addition, the PAI teacher also directed the commemoration of Islamic holidays, so that the Islamic atmosphere was more pronounced. Briefing and coaching activities in general aim to improve students' good character, increase Islamic knowledge, be trained to think positively, increase sensitivity to Islamic holidays, all of which have a positive effect on student achievement in class.(Syamsu Yusuf LN, 2004, p. 36) 
Rohis activities at SMPN 17 Bandung include: 1) Islamic learning through the group method every week; 2) Islamic learning in the open; 3 ) The night of building faith and piety (mabit); 4) Read and write the Koran (BTA); 5) Improved reading of the Koran with applicative recitation (tahsin); 6) Motivational training to balance intellectual intelligence, spiritual intelligence and emotional intelligence; and 7) Study groups to produce high-achieving Muslims through competitions such as tahfiz competitions, call to prayer competitions, calligraphy competitions.(RI Ministry of Religion Regulation of the Director General of Islamic Education Number Dj / 12A of 2009)

It is an agreement with the school that organizes Rohis extracurricular activities with the Ministry of Religion, in this case the Director General of Islamic Education through regulation Number Dj.I / $12 \mathrm{~A}$ of 2009. It was agreed that this Rohis implementation is an effort to improve moral values, foster faith and piety, practice, so that formed a personality in accordance with Islamic principles. This Rohis arrangement is under the guidance of school religion teachers.

Rohis (Kerohanian Islam) is an organization or school da'wah forum to spread the values of goodness both through organizing activities and through the examples shown by Rohis members every day. Rohis is also a partner of the main student organization, namely the Student Council. As a school organization, Rohis has a management structure like an activity of student, has a chairman, treasurer and secretary, as well as other divisions, according to the conditions and needs of the school. Rohis also has a work program and articles of association and household which will later form the basis for activities.

Humans who grow up always have a burning passion at every moment of life. Likewise happened to junior high school students, who are experiencing a psychological transition between children and early adolescents. Even though they are in a transitional psychological condition, students bring their interest in one specific thing. Including the interest to learn more about PAI. Students can show a high interest in learning Islamic Education by entering Rohis. Interest is a high heart inclination toward something or passion and desire; stick to something valuable according to their needs. The stronger or closer the relationship, the greater the interest.(Ngalimu, 2016, p.36)

This strong desire is one source among several learning resources. A strong desire is often associated with motivation to learn or the urge to learn about something new. A strong desire is often called an interest in education. High student interest will be seen in good learning outcomes, and vice versa.

Having a strong interest in learning arises because there is acceptance from the environment. Self-acceptance by the environment will form conformity and give each other positive energy.

The meaning of interest approaches the word motivation or encouragement. Motivation is often associated with a person's interest in one thing, in a field such as work, or in college. When attraction arises, positive energy will emerge which is an impetus to do something even though there are many obstacles in your way. Interest is a source of motivation for a person to do what he wants which is closely related to cognitive, affective, and motoric aspects.

Human development is influenced by two factors, namely those that are internal and external. A factor that comes from within is an impulse that arises from a high desire or passion, it can be in the form of talent or nature from birth or something that has been conditioned by both parents since in the womb. External factors are high motivation or desire because they are influenced by other people. Hansen stated that interest in learning is closely related to personality, motivation, expression and selfconcept or identification, as well as heredity and external or environmental influences.(Yudrik Zahya, 2013, p. 63) 
Understanding the concept of learning is very important for teachers, because implementing learning theory will provide solutions to students and the learning environment, especially when the learning process takes place. The definition of learning that we often hear, includes learning, is a series of planned and systematic activities. The meaning is an effort to gain intelligence or knowledge by reading and practicing, so that there is a change in behavior for a better or a response about something caused by experience. Saeful Bahri, argues that in the learning process there are two main elements, namely body and soul. Raga shows movement in the learning process, namely continuous practice until it can. The soul shows invisible activities including awareness, taste and thought processes. So that the soul shows change, through good and better actions / behavior. Changes in the soul affect changes in student behavior.(Djamarah, 2011, p. 12) Research related to this research is

Ali Noer. Syahrini Tambak, Harun Rahman, Extracurricular Efforts of Islamic Spirituality, in increasing the diversity of Students at SMK Ibnu Taimiyah Pekanbaru, Al-Thariqah Journal Vol. 2, No. 1, June 2017, stated that the efforts of Rohis activities at SMK Ibnu Taimiya Pekanbaru increase student diversity.(Noer et al., 2017, p.21)

Indah, Ahmad Syamsu Rizal, and Toto Suryana, Religious Extracurricular Activities in Schools to Support the Achievement of PAI Learning Objectives at SMP 44 Bandung, Tarbawy Journal, Vol 2 no. 1. 2015. In general, the implementation of Islamic Education learning runs smoothly, while the management of religious extracurricular activities is not optimal.(Ahmad Syamsu Rizal, A. Toto Suryana A., 2015, p. 82)

Rizki Susanto, Utin Kusntianing, Extracurricular Implementation of Islamic Religious Education at SMPN 3 Malang, JRTIE Journal, Vol 2, No. 1. 2019, activities carried out by Rohis include Imtaq, performing midday prayers and Friday in congregation, recitation of female students, consultation on Islam, Al-Quran reading programs, Tahfiz, charity programs, PHBI, and Ramdhan activities(Rizki Susanto and Utien Kustianing, 2019, p.77)

Rokib, The Influence of Extracurricular Spiritual Islam (Rohis) on PAI Learning Outcomes in Class X Students of SMAN 5 Tangerang, UIN Jakarta 2018 Thesis, revealed that there is an influence between spiritual activities and student learning outcomes at a moderate degree.(Rokib, 2018)

Febri Agung, The Effectiveness of Islamic Spiritual Extracurricular (Rohis) in Improving Student Learning Outcomes of Widyatama Junior High School in Bandar Lampung, the Thesis of UIN Raden Intan suggests that improving Islamic Education learning outcomes for Widyatama Junior High School students is taken by 1) students follow Rohis and practice reading the Koran, 2) Method used are lectures and questions and answers, 3) assessment in Rohis includes active assessment, attitude, daily tests, and semseter exams.(Febri Agung, 2017).

\section{RESEARCH METHODS}

The research location was conducted at SMPN 17 Bandung. The research procedure was carried out based on population and sampling. Population is the whole object to be studied(SuharsimiArikunto, 2013)namely students of SMPN 17 Bandung who are active in Rohis totaling 30 people. Meanwhile, if the object taken is less or part of the total population due to the limitations of the researcher, it is called a sample.(Sugiyono, 2017, p. 118)

Technically the research discusses several things, namely:

1. The interaction between teachers and students is marked by a mutual influence between Islamic education teachers and students to be active in Rohis activities at SMPN 17 Bandung. This is shown by good communication between Islamic Education teachers and students and students' interest 
in the personality of Islamic Education teachers. Students believe what the PAI teacher says.

2. Spiritual activities are able to boost students' interest in liking spiritual activities.

3. The growing interest in studying religion outside of PAI material in the classroom and the development of religious interest in spirituality at SMPN 17 Bandung 083152257666

This study plans and carries out data collection including through:

a. Observation. Researchers made several observations before then conducted interview activities, and distributed questionnaires to Rohis members. This action is based on Sugiyono's opinion which states that researchers can work based on data which includes reality or facts, namely everything about reality in the focus of the research. All of this is obtained through observation.(Sugiyono, 2017, p. 308)The observation method is a research method by observing directly and systematically recording the object under study. This observation was also carried out by observing student activities in Rohis activities. Furthermore, knowing the involvement of students, including student activity, the activity of coaches whose age is not far from the students asked by the religion teacher. Then this observation is followed by interview activities. and

b. The interview activity is a researcher activity among three activities. The purpose of this interview is to get direct results from the Islamic Education Teacher, and Students as well as several school sources or other informants. Informants are people who have a direct connection with Rohis activities at school. The researcher's interview activity was carried out by asking several questions in accordance with the grid that had been made. The purpose of this interview is to gather as much information as possible without changing it or to influence the respondent's opinion during the interview.(Cholid Narkubo, 2013, p.86)

c. Data collection and questionnaires, namely by distributing statement sheets to students about matters related to student interests, the role of teachers in spiritual activities at SMPN 17 Bandung. After the data was collected, the researcher carried out the next process, namely editing, which was an activity carried out after the questionnaire was collected. In the process, the researcher checks back the data that has been obtained, the aim is to maintain and guarantee validity (vaiditas). In the second stage, the researcher did tabulating and coding. This activity involved grouping similar answers systematically. The coding stage is carried out by compiling in the form of a table, then coded. Then the data is interpreted, Furthermore, activity 1) data reduction (data reduction) which is also called the process of selecting, simplifying, and transforming rough data that appears from written notes in the field. Its function is to sharpen, classify, direct, remove unnecessary, and organize so that biased interpretations are drawn. (Cholid Narkubo, 2013, p.209) 2): presenting data (Data Display,) from a set of information arranged, grouped into sections and subsections of each data obtained from the field, the aim is to make it easier to read and make conclusions. (Cholid Narkubo, 2013, p.209). 3) Conclusion (Conclusion Drawing) is an effort to construct, interpret data to get an in-depth understanding of the problem being studied.(Cholid Narkubo, 2013, p.210) To support the accuracy in calculating the correlation in this study, the researchers used SPSS 20.

\section{RESULTS AND DISCUSSION}

School is a place of activity for students according to their developmental age. Students who are active in extracurricular activities when compared to the total number of students are only about $10 \%$ who are scattered in all extracurricular activities organized by the school. Rohis at SMPN 17 Bandung is named Garis Madu, which stands for the Darul Ulum Mosque Muslim Youth Association. Rohis activities carried out at SMPN 17 are of interest to students, this is evidenced by the 30 students who are active in Rohis, and more when 
compared to other extracurricular activities. Students who are active in Rohis are not only in certain classes but all levels, there are both grades 7, 8 and 9. Recruitment of Rohis members is more dominant through personal approaches, for example from class seniors to juniors, besides the presence of Rohis at student orientation moments new, generate interest in new students to be active in Rohis. This was proven when the researcher met directly with the Rohis members, there were some people who were grade 7 students. Unfortunately, this Rohis activity was still dominated by female students, while male students were more interested in masculine extracurricular activities such as scouts, paskibraka, and martial arts.

Senior Islamic education teacher at SMPN 17 Bandung as the second respondent in this study. Mr. Aceng is a senior teacher with 15 years of work as a religion teacher at SMPN 17 Bandung. He is very passionate about the profession as a religion teacher. His job is not only as a teacher with the task of planning, managing and evaluating Islamic Education learning, but also as chairman of the DKM mosques in schools. Because the scope of the mosque is relatively small, Mr. Haji Aceng Zaenal Mutaqin also has responsibility for the cleanliness, tidiness and activities of the mosque. The mosque is the center of Rohis activities. Pak Aceng's simple, firm and relaxed profile is easy for students to accept in all classes. Even though there are other religious teachers, it seems that Pak Aceng's role as a senior is more dominant.

The principal of SMPN 17, Mr. H. Saan Ruswandi, really cares about the continuity of Rohis activities, considering that PAI teachers have carried out the mandate according to their main duties and functions. The school principal took the initiative to mandate routine guidance for Rohis activities to a coach who came from a mosque youth and was well known for his Islamic knowledge by the school. This coach is regularly present every Wednesday afternoon after the learning process is over. The main activities of the supervisor are giving tausiah that is appropriate for the age of the student, teaching reading the Koran properly, together with the PAI teacher directing student activities including preparing for mabid, orienting new students, organizing Islamic holidays.

Researchers distributed three types of questionnaires to students of Rohis activists, namely questionnaires related to the teacher's role, student interests, and Rohis activities. After tabulating the questionnaire, the validity test is used to measure the validity of the data and check the similarity between the data collected and the actual data that occurs on the object of research. ${ }^{1}$

a. The validity test aims to test the validity of the research instrument per item, through a comparison between $\mathrm{R}$ count and $\mathrm{R}$ table. In this study using the formula $\mathrm{N}-2=\mathrm{df}$. To determine the $\mathrm{R}$ count, the researcher conducted validity through a linear regression formula. Obtained data like the table below. $\mathrm{R}$ table at the standard validity of 0.05 or $5 \%$ can get $r$ table $=0.361$. The table shows $\mathrm{R}$ count $>$ from $\mathrm{r}$ table, it can be concluded that the question items per variable are valid. Validity testing uses SPSS 20 with the formula $\mathrm{R}$ count greater than $\mathrm{R}$ table. The conclusion was that each questionnaire point about the role of the teacher was greater than $\mathrm{R}$ table $(0.361)$, namely between 0371-0726, the students' interest R counted between $0.380-778$, and Rohis R counted 0.360-0.703.

b. After being declared valid, the researchers conducted reliability testing to determine the level of consistency and stability of an instrument. Reliability testing using SPSS 20.

The basis for testing reliability using the basic criteria of Nunali (1960), according to him, if the Cronbach alpha value is greater than $60 \%$, the questionnaire is considered 
reliable. In the table above, Cronbach's alphabet is $74.2 \%$ greater than $60 \%$, so the questionnaire variable $\mathrm{X} 1$ is reliable.

c. Kolmogorov-Smirnov Normality Test. The data used are normal data, which is proven by the Kolmogorov-Smirnov-based normality test. This test uses SPSS 20 . The results obtained are based on the results of normality, it is known that the significance value is $0.842>0.05$, so it can be concluded that the residual value is normally distributed.

d. Correlation test. This correlation test is the center of this research, because it is to answer the existing problem formulations, as well as prove the hypothesis that is the basis of quantitative research. This correlation test uses SPSS 20 which is the media in this study.

The basis for decision making using SPSS, it is found that the Model Summary table is in the Sig. F. Change the number obtained by 0.032 . The guideline used is if the Sig. F value is $<0.05$ then it is correlated, if the Sig. F Change> 0.05, so there is no correlation. Here is found Sig F. Change 0.032 . The number 0.032 is proven to be smaller than 0.05 , thus this study proves the hypothesis that the teacher role $\mathrm{x} 1$ variable, and the student interest variable $\mathrm{x} 2$, are related to the y1 variable, namely Rohis activities. there is a relationship between the role of the teacher and students' interest in spiritual activities.

After getting the correlation on these three variables, the next activity is to determine the degree of the relationship. The basis for determining the degree of this relationship is the Pearson correlation. To determine the degree of association on the Pearson correlation, or to provide interpretation of the correlation coefficient or also to use guidelines can be called the basis of interpretation. Guidelines for correlation coefficients using guidelines from Sugiyono, can be called the basis for interpreting the correlation coefficient of the relationship.

Obtained Pearson Correlation Value 041 to 0.60 the value obtained in the calculation of
Perason's correlation is 0.474 which is in the middle position. Through the results of the Pearson Correlation, one conclusion can be drawn about the degree of correlation, namely this study shows a moderate degree of correlation. This is evidenced in the Model Summary table, there is a column $\mathrm{R}$ which amounts to 0.474 .

After testing the validity and reliability, normality, correlation, and degree of correlation, through SPSS 20, it was found that there was a positive correlation between the role of the PAI teacher which is $\mathrm{X} 1$ and student interest which is $\mathrm{X} 2$ towards Rohis activities / activities as Y1. This evidence shows that the hypothesis which states that there is a relationship between the role of Islamic Education teachers and student interest, has an effect on the high student participation in Rohis activities at SMPN 17 Bandung, is proven.

\section{CONCLUSION}

The role of Islamic Education Teachers in schools has four roles, namely as educators, the main role of Islamic Education teachers, supervisors; directing and fostering, motivating, and as a student evaluator. More specifically, the role of the PAI teacher at Rohis Garis Madu as a guide and motivator for students. As a motivator, the PAI teacher encourages, directs and invites students to be active in every Rohis Honey Line activity. The role of the PAI teacher as a guide is to foster, preserve activities, maintain students to continue to be active in Rohis Madu Line. Guidance to students in the form of lectures on youth religion, for example youth fiqh, social morals, discussion of issues that occur and tips on how to respond to them. In addition, the PAI teacher also motivated and together with the students held an event to commemorate Islamic holidays, involve students in good habituation activities at school so that the Islamic / religious atmosphere is more pronounced. The closeness of the PAI teacher is so felt that it raises students' interest to learn PAI and is active in Rohis Honey Line. In addition, the 
character of the PAI teacher who is flexible can position him as a teacher and as a friend of the students, so that students feel close to him.

The students' interest in becoming members of Rohis is also due to the role of the Principal who is very concerned about the continuity of Rohis activities by providing a young Rohis coach, who is directly under the supervision of the PAI teacher. This is very useful, especially for the 30 students who actively participate in the activities.

After being tested using SPSS 20 regarding the relationship between the role

\section{REFERENCES}

Abdulsyani. (2002). SosiologiSkematika, Teori, danTerapan. Sinar Grafika.

Ahmad Syamsu Rizal, A. Toto Suryana A. (2015). Kegiatan Ekstrakurikuler Keagamaan Di Sekolah Dalam Menunjang Tercapainya Tujuan Pembelajaran Pai (Studi Deskriptif Analisis di SMP Negeri 44 Bandung Tahun Ajaran 2014/2015). Tarbawy, 2 No 1(Pendidikan), 82.

Cholid Narkubo, A. A. (2013). Metode Penelitian. PT BumiAksara.

Djamarah, S. B. (2000). Guru dan Anak Didik dalam Interaksi Edukatif. Rineka Cipta.

Djamarah, S. B. (2011). Psikologi Belajar. PT. Reneka Cipta.

Febri Agung. (2017). Efektivitas Kegiatan Ekstrakurikuler Keagamaan (Rohis) Dalam Meningkatkan Hasil Belajar Siswa di SMP Wiyatama Bandar Lampung.

Hamka Abdul Aziz. (2012). Karakter Guru Profesional. Al Mawardi Prima.

Muhaimin. (2005). Studi Islam dalamRagamDimensidanPendekatan. Prenada.

Ngalimu, dkk. (2016). Strategi dan Model Pembelajaran,.

Yogyakarta:

AswajaPressindo.

Noer, H. M. A., Tambak, S., \& Rahman, H. (2017). Upaya Ekstrakurikuler Kerohanian Islam (ROHIS) dalam of Islamic Education teachers and students' interest in Rohis activities, it was obtained that $r$ count was 0.474 greater than $r$ table 0.361 at a significance level of $5 \%(0.05 \%$ on $r$ table). There was a variable relationship $\mathrm{X} 1$ the role of Islamic Education teachers , student interest variable $\mathrm{X} 2$, towards $\mathrm{Y}$ Rohis Honey Line activities. In this study, it can be concluded that the role of Islamic Education teachers in guiding and motivating, as well as students' interest in learning Islamic Education is closely related to the activities of the Honey Line Rohis.

Meningkatkan Sikap Keberagamaan Siswa di SMK Ibnu Taimiyah Pekanbaru. Jurnal Pendidikan Agama Islam Al-Thariqah. https://doi.org/10.25299/althariqah.20 17.vol2(1).645

Poerwadarminta. (2007). Kamus Umum Bahasa Indonesia. Balai Pustaka.

Rizki Susanto dan Utien Kustianing. (2019). Pelaksanaan Ekstrakurikuler Pendidikan Agama Islam Di Sekolah: Studi di SMPN 3 Malang Tahun 201. JRTIE: Journal of Research and Thought of Islamic Education, 2(pendidikan), 77.

Rokib. (2018). Pengaruh Ekstrakurikuler Rohani Islam (Rohis) Terhadap Hasil Belajar PAI Pada Siswa Kelas X SMAN 5 Tangerang.

Soekanto, S. (1990). Sosiologi Suatu Pengantar, Edisi IV. In Jakarta, Penerbit Rajawali.

Sugiyono. (2017). Metode Penelitian Pendidikan Pendekatan Kauntitatif, Kualitatif, R\&D. In Metode Penelitian Pendidikan Pendekatan Kuantitatif, Kualitatif Dan $R \& D$.

SuharsimiArikunto. (2013). Produser Penelitian Suatu Pendekatan Praktik (Rineka Cipta (ed.)).

Syamsu Yusuf LN. (2004). No Title Psikologi Belajar Agama. Pustaka Banin Quraisyi. 
Tarbiyah: Jurnal Ilmiah Kependidikan

Vol. 9 No. 2. July - December 2020 (130-139)

DOI: http://dx.doi.org/10.18592/tarbiyah.v9i2.3698

Yudrik Zahya. (2013). Psikologi Prenadamedia Group, 2013, hal.63.

Perkembangan. Jakarta: 